\title{
The French Municipal and European Elections, 2014 RAYMOND KUHN
}

Queen Mary University of London

The 2014 municipal and European elections were second order electoral contests in France, with neither the tenure of the supreme office of the presidency, nor the balance of power between parties in the National Assembly in contention. In theory voters were simply electing town and city councillors in the first contest and constituency representatives to the European parliament in the second. Yet in practice these two sets of elections, held within the space of a few weeks in the spring, were far more important than what was formally at stake, since they had potentially significant consequences for the three main competing blocs in the French party system: the left, the right and the extreme right.

First, these were the first major nationwide tests of voter opinion to take place since the presidential and parliamentary elections of 2012 that had resulted in the accession of François Hollande to the presidency (the first Socialist presidential victory since 1988), the election of a left-wing majority in the National Assembly and the formation of a coalition government composed mainly of Socialist party heavyweights but also including ministers from other formations on the left, including the centre-left Parti radical de gauche and the enivonmentalists, l'Europe-Écologie-Les Verts (EELV) (Kuhn, 2013). Coming three years before the scheduled date of the next set of presidential and parliamentary elections, the 2014 municipal and European contests thus constituted a major mid-term test for president Hollande, his government, the Socialist party and the left as a whole. Moreover, since the Socialist party had previously performed extremely well in municipal elections, the Socialists were defending their implantation in a wide swathe of towns and cities across France, where they had benefited from sub-national power bases that served to offset their lack of success in national presidential and parliamentary elections in both 2002 and 2007.

Second, the 2014 elections provided the opposition party of the mainstream right, l'Union pour une Majorité Populaire (UMP), the opportunity to assess the extent to which it had recovered from its defeat in the 2012 presidential and parliamentary elections, from the loss of its de facto leader and defeated presidential incumbent, Nicolas Sarkozy, and from the bitter infighting that had followed the disputed election 
of Jean-François Copé to the position of leader of the party in the autumn of 2012. While the UMP naturally hoped to benefit from the unpopularity of president Hollande and his government, the party was far from presenting a united front behind Copé. Instead, in the absence of the binding cement of power the party was fragmented, lacked a coherent strategy with regard to how to adapt to the challenge posed by the Front National (FN) and was divided over key policy issues (Haegel 2012). In particular, among UMP elite figures the mixed legacy of the Sarkozy presidency (2007-12) and conflicting views regarding the desirability of his return to active politics made it difficult for the party to draw a line under the period of Sarkozy's dominance of the UMP that stretched back at least as far as his election to the leadership of the party in 2004 (Guénolé 2013; Paillé 2013).

Finally, the 2014 elections would reveal the extent to which the 'detoxification' strategy of Marine Le Pen had succeeded in extending the electorate of the FN and broadening its social base with the aim of posing an effective challenge to the dominance of the right of the party system by the UMP. Since taking over the reins of the party from her father in 2011 Marine Le Pen had tried to tone down the more explicitly racist and anti-semitic elements of FN discourse that had been such a notable feature of Jean-Marie Le Pen's public interventions during the long period of his leadership. As part of the rebranding exercise she had also refused the application of the term 'extreme right' to the FN (Igounet 2014: 406-53). The extent to which her 'detoxification' strategy represented a substantive moderating shift in the party line or was simply a cosmetic marketing exercise to make the party more acceptable to voters had been an intriguing aspect of her presidential campaign in 2012 (Shields 2013) and had remained a constant issue of political and media debate thereafter.

\section{The political context 2012-14}

The political context for these mid-term elections was the deep unpopularity of president Hollande and his government. By the spring of 2014 Hollande had become the least popular president in the history of the Fifth Republic, surpassing all six of his predecessors in this respect. The sluggish performance of the French economy, high levels of unemployment, the introduction of unpopular taxation measures, the cost of living and the pervasive sense of a nation not just in decline but without effective 
leadership to turn the situation round - all were contributory factors in the mix of voter discontent which established itself in the early months of Hollande's presidential term.

Hollande had been elected to the presidency in 2012 to a large extent on the basis of electoral disaffection with Sarkozy. There had been no huge groundswell of popular enthusiasm for Hollande's candidacy, nor had he made grandiose promises to address France's economic situation. This meant that while Hollande provided few hostages to fortune, he also did little to suggest that his presidency would be marked by radical reform. Yet while Hollande did not unduly raise voter expectations, he certainly suggested that economic performance would be better under his stewardship, that unemployment would decrease and that most voters would be better off as France emerged from the financial and economic crisis years that had dominated much of Sarkozy's presidential term.

Voter disappointment set in quickly and by the autumn of 2012 Hollande's popularity started to decline (see Table 1). Public discontent with Sarkozy had been as much a question of style as of substance - a feeling of unease with a president whose mediatised hyperactivity was not reflected in policy success and who failed to live up to the template of presidential leadership established by the founding father of the regime, General de Gaulle. In the case of Hollande voter perception of the new presidential style also played a part in their disaffection. Hollande's initial decision to stand back from being an interventionist head of state - a reaction to Sarkozy's approach - and to present himself as an 'ordinary president' (président normal) failed to impress voters, who expected the chief executive to demonstrate that he had taken full charge of France's problems. With unemployment continuing to increase inexorably, economic growth proving disappointingly sluggish at best, firms closing at an alarming rate and the country failing to meet its public sector deficit to GDP ratio set by the EU, the sense that the policies of the new president were not up to dealing with France's parlous economic situation - and most particularly the issues of growth and employment - took root. The Cahuzac affair in the spring of 2013, in which the Minister for the Budge in charge of fiscal fraud was exposed as illegally possessing an undeclared foreign savings account and as having lied to the president and the National Assembly, effectively sabotaged Hollande's aspirtations to occupy the moral high ground on the issue of financial scandals (Chaffanjon 2013).

One might have anticipated that the problems of Hollande would have automatically benefited the mainstream opposition party, the UMP. In fact this was far 
from the case. After the 2012 defeats in the presidential and parliamentary elections, the UMP had become deeply divided on the issues of leadership, strategy and policy (for example, over the controversial and highly emotive question of gay marriage and the perennial problem of Europe). In November 2012 the party leadership contest which pitted François Fillon, Sarkozy's prime minister during the five years of his presidential tenure, against Copé, former head of the UMP parliamentary group and then general secretary of the party, was a bitterly contested affair, particularly with regard to the mechanics of the voting process (with allegations of vote rigging from both sides) and the final count (where to Fillon's disadvantage some votes from overseas were inexplicably excluded). Copé was declared the narrow winner, a result which Fillon initially refused to accept and which for a short while threatened to tear the party apart (Barjon and Jeudy 2013). This deep conflict over the leadership was underpinned by the assumption that control of the party organisation was a necessary, if not sufficient, condition for successful election as the UMP's presidential nomination in the party primaries that were scheduled to be held in advance of the 2017 presidential contest.

The leadership contest on the right was also driven by a different evaluation of the UMP's ideological positioning in the party spectrum. Fillon was more inclined to see the UMP as a traditional conservative party that needed to stay close to the centre ground, while Copé was more ready to move the party in a strong rightwards direction with the aim of attracting FN voters. In this respect Copé was more prepared than Fillon to accept the campaign strategy in pursuit of voters from the extreme right undertaken by Sarkozy during the 2012 presidential campaign. This difference in approach between Fillon and Copé reflected a broader distinction on the stance to be adopted by the UMP towards the Front National: because of the extreme nature of its views should the FN be regarded as a party with pariah status, beyond the pale of mainstream political competition, or because of its growing electoral popularity should the FN be viewed as a 'normal' party with a full role to play in representative democratic politics?

During the first two years of the Hollande presidency the FN under the leadership of Marine Le Pen had continued its strategy of 'detoxification' (dédiabolisation) in an attempt to widen its electoral appeal with the objective of replacing the UMP as the major party of the right. This strategy had already paid electoral dividends in the 2012 presidential contest, where Marine Le Pen had attracted both a higher number of votes 
and a greater proportion of women voters than her father had ever been able to do in five previous presidential elections. Thus, prior to the 2014 elections Marine Le Pen had already broadened the sociological composition of the FN electorate to make it more reflective of French society as a whole. Not only had voting for the FN become more acceptable among different social strata (with the notable exception of the better educated), but fewer voters than before considered the FN to be a 'danger for democracy in France'. While between 1985 and 2012 a majority of between 50\% and $75 \%$ of voters had considered the FN to be such a threat, at the start of 2013 this figure had dropped to 47\% (Perrineau 2014: 76). The FN had become more respectable, with $32 \%$ of voters in agreement with the ideas of the party at the start of 2013 , the highest figure since 1985 and equalled only once previously, in 1991 (Perrineau 2014: 75).

\section{The 2014 municipal election}

At stake in the municipal elections was the renewal of councils across the whole of France in over 36,000 communes of hugely differing size, with many under 1,000 inhabitants. In the small communes perception of the managerial competence of candidates frequently overrode party political considerations in influencing voter preferences. Control of all major towns and cities, including Paris, Marseilles, Lyons, Bordeaux, Lille and Toulouse, was an integral part of the contest, which was fought over two rounds on 23 and 30 March. In communes of over 1,000 inhabitants the electoral system was a proportional list system with a majority bonus to the winner. In the first round a list which gained an absolute majority of votes and the support of at least a quarter of registered voters was allocated $50 \%$ of the seats, with the remainder of seats being shared among all the lists obtaining at least $5 \%$ of the vote. If no list obtained an absolute majority in the first round, a second round took place in which those lists that obtained at least $10 \%$ of the vote in the first round were allowed to stand; lists which obtained at least $5 \%$ in the first round could merge with one of the lists that had automatically qualified for the second round. In the second round the list that came first was allocated $50 \%$ of the seats and the remainder of seats was shared among all the lists that obtained at least $5 \%$ of the vote. In line with parity legislation all party lists had to consist of an alternating candidate of each sex. 
Turnout in the first round was $63.55 \%$, compared with $61.05 \%$ in the 2008 contest and $61.46 \%$ in 2001 (Ministry of the Interior 2014a). The official total vote share in the first round is given in Table 1:

Table 1: Vote share of party lists in the first round of the 2014 municipal election

Extreme left

Front de gauche

Parti de gauche

Communist party

Socialist party

Union of the left

Other left

EELV

Others

Modem

Union du Centre

Union Démocrates et Indépendants

UMP

Union of the right

Other right

FN

Extreme right
0.60

0.32

6.62

11.40

15.88

1.16

9.97

0.49

0.48

2.33

6.90

11.61

24.57

4.76

0.12

Source: Ministry of the Interior 2014a.

In the contest between the two loose blocs of mainstream left and right, the latter were the clear victors in the first round. While no major town or city was won by the left in the first round, in contrast the UMP retained Bordeaux, Le Havre, Orléans and Toulon. The extreme right retained Orange in the south of France and, with just over $50 \%$ of the vote, registered a spectacular victory in winning Hénin-Beaumont in the north-east from the left.

The victory of the National Front in Hénin-Beaumont, where Marine Le Pen had narrowly lost in the 2012 parliamentary election, was a major news story of the first 
round. Hénin-Beaumont was a town where the National Front had long sought to make a symbolic electoral breakthrough (Sabéran 2014). Located in a former coal mining area, the town was a victim of the deindustrialisation that has affected so many parts of France since the long postwar period of economic growth began to come to an end in the early 1970s. The town has suffered from very high levels of unemployment (almost twice the national average in 2014), especially among the young, and exhibited many signs of social deprivation and family poverty, as well as a breakdown in traditional forms of collective solidarity.

Politically the town had for many years been a bastion of the Socialist party. In recent years the Socialist council had engaged in clientelistic practices and financial corruption in a bid to maintain its political hold at the local level, leading to successful criminal charges being brought against the mayor. The lead candidate on the FN list, Steeve Briois, had campaigned in the town for twenty years, helping to contribute to a steady increase in the FN first round vote share in successive municipal elections since 1995 (12.92\% in $1995 ; 17.49 \%$ in $2001 ; 28.53 \%$ in $2008 ; 50.25 \%$ in 2014$)$. For many

of the town's inhabitants the weakness of successive national governments of right and left to address their problems left them open to voting for the FN, while for Marine Le Pen the town quite simply symbolised the abandonment of the working class by the left (Brigaudeau 2014).

Turnout in the second round was $62.13 \%$, compared with $62.16 \%$ in the 2008 contest and $62.39 \%$ in 2001 (Ministry of the Interior 2014a). The official total vote share in the second round is given in Table 2:

Table 2: Vote share of party lists in the second round of the 2014 municipal election

Extreme left 0.05

Front de gauche 0.93

Parti de gauche

Communist party

Socialist party

Union of the left

Other left 
Modem

Union du Centre

Union Démocrates et Indépendants

UMP

Union of the right

Other right

FN

Extreme right

Source: Ministry of the Interior 2014a.

After the second round it was clear that the municipal election results represented a significant victory for the mainstream right in general and the UMP in particular and a crushing defeat for the left in general and the Socialist party in particular. The left lost control of 151 towns of above 10,000 inhabitants (including some where it had been in charge for many years such as Limoges, Chambéry, Nevers and Pau) while the UMP gained 142. In the second round the right gained the following large towns/cities: Amiens, Angers, Argenteuil, Caen, Limoges, Reims, Saint-Étienne, Toulouse and Tours. Within the left the Socialist party lost Grenoble to the EELV. A small handful of councils was won by the extreme right, including Béziers and Fréjus in the south. The left retained Lyons; the UMP held on to Marseilles, where the local Socialists were tainted by corruption allegations and the FN won in one electoral district. The front page headline in Le Monde following the second round summed up the scale of the defeat for the left: 'Hollande pris dans le piège d'une déroute historique' ('Holland caught in the trap of a historic collapse') (Le Monde, 1 April 2014).

The major success story for the left was the retention of Paris, bastion of the right between 1977 (the first municipal election in the capital) and 2001. The contest in Paris was led by two women: the outgoing deputy mayor, Anne Hidalgo (Socialist) versus the former government minister and UMP parliamentary representative, Nathalie Kosciusko-Morizet. Yet although a highly personalised contest in terms of media coverage, the election in Paris was not a presidential-style direct election between individual candidates. Instead it was a contest that involved parties contesting 
seats at the level of the twenty districts (arrondissements) within the city boundaries a system that in the eyes of experts made it more difficult for the UMP than for the Socialist party to gain a majority because of the disparity between votes and seats.

Kosciusko-Morizet clearly saw her election to the Paris mayorship as a stepping stone to a possible presidential nomination in 2022. Yet although her candidacy in the capital received the official support of the two centrist parties, l'Union des Démocrates et Indépendants (UDI) and Mouvement Démocrate (Modem), she antagonised many within the upper echelons of the UMP in Paris for being (singly or in combination) an outsider, a woman, too moderate in policy terms and too authoritarian in leadership style. Koscuisko-Morizet seemed to spend as much time responding to criticism from within the ranks of her own party as putting forward policy proposals or attacking the Socialists. While the UMP list had a narrow lead in the first round, in the second round the transfer of votes across the left ensured a convincing victory for Hidalgo. The UMP came first in nine districts, the Socialists in ten and the Greens in one. Paris was one of the few parts of France where the FN made no significant inroads in terms of vote share and the party won no seats on the city council. The distribution of the 163 seats on the city council is given in Table 3.

Table 3: Allocation of seats on Paris city council, 2014

Parti de gauche: 1

Communist party: 13

EELV: 16

Socialist party: 60

Left Radical party: 2

Modem: 6

Union Démocrates et Indépendants: 10

UMP: 55

Source: Le Monde, 1 April 2014.

Because of more stringent parity legislation there was a larger number of female candidates and councillors nationwide than previously. The gender balance of those elected was roughly $60 / 40$ per cent in favour of male 
councillors. While this represented an improvement for women $(21.7 \%$ female councillors in 1995, 31.7\% in 2001, 35.0\% in 2008) (Ministry of the Interior $2014 b$ ) the latter were more rarely placed at the head of party lists. Indeed $87 \%$ of party list were headed by a man (Vaudano 2014). In short, in terms of gender equality women had made significant strides by 2014 in terms of candidacies and elected councillors, but significantly less so in terms of mayorships. Nonetheless, after the municipal election the following large towns/cities had a woman mayor: Aix-en-Provence, Amiens, Lille, Montreuil, Nantes, Rennes and, of course, Paris.

Finally, it should be noted that since mayors and local councillors are responsible for electing representatives to the upper house of the French parliament, the municipal results meant that the left was almost certain to lose its slim majority in the Senate in the elections to the upper house in the autumn of 2014. The Socialists' belief - feigned or sincere - that the municipal elections were local contests that would be fought on local issues and that their town hall record would stand them in good stead had proved to be well wide of the mark. Instead it was clear that many voters had taken the opportunity to sanction the president and his government, while many Socialist party supporters had simply abstained to show their disaffection. Socialist-dominated councils had paid the price for presidential unpopularity.

\section{The 2014 European election}

In the European election held on 25 May French voters were asked to elect to a total of 74 seats in the European parliament (an increase of two from the previous contest in 2009). The electoral system used was a list system (with closed lists and no preferential voting) in eight inter-regional constituencies (including one for overseas territories). There was only one round of voting, with seats being allocated on the basis of proportional representation, using the highest average (the D'Hondt system). Seats in each constituency were divided between those party lists that obtained at least 5\% of votes cast, with seats allocated to specific candidates according to the order of names on each party list.

Across France as a whole there were no fewer than 193 different lists in contention, an increase of 32 from 2009. Media coverage, however, was dominated by the campaigns of the big three: the Socialist party, the UMP and the FN. As in many 
other member states of the European Union, the campaign was characterised by a strong Eurosceptical flavour, with one opinion poll just prior to the vote showing that only $39 \%$ of voters considered French membership of the EU to be a 'good thing', with $22 \%$ thinking the opposite and $39 \%$ unable or unwilling to state a preference ( $L e$ Monde, 20 May 2014). Despite a government announcement concerning the introduction of tax cuts for the less well off, the Socialist party feared another humiliating rejection by voters in the wake of the municipal election debacle. The UMP was focused less on outdistancing the Socialists (a result which was taken for granted well in advance of polling day) and much more on coming ahead of the FN. The FN's objective was to take advantage of the predicted lowish turnout and the strong mobilisation of its electorate to become the leading party across the country.

The turnout in the European election was $42.43 \%$, compared with $40.63 \%$ in 2009 and $43.1 \%$ in 2004 (Ministry of the Interior 2014c). For the first time in a nationwide election the Front National came out on top (24.86\% of the vote). This was dramatically up from its vote share of $6.34 \%$ in 2009 . The UMP trailed well behind with $20.81 \%$ of the vote (a significant drop from $27.88 \%$ in 2009 ). The Socialist party came third with a humiliating $13.98 \%$ vote share (down from $16.48 \%$ in 2009). Other leading party formations in terms of vote share were: the Centrists (9.94\%); the EELV (8.95\%, massively down from their vote share of $16.28 \%$ in 2009$)$; the Front de gauche $(6.33 \%)$; and diverse left $(3.18 \%)$.

\section{Table 4: Vote share and seats of party lists in the 2014 European election}

Vote share Seats

Extreme left 1.60

Front de gauche

13.98

3.18

8.95

4.37

Others

9.94

20.81

5.98

Other right
3

13

1

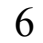

7

20 
Extreme right

Source: Ministry of the Interior 2014c.

The main victors of the election were clearly the FN. The party secured a total of $4,712,461$ votes (compared with just under six and a half million for Marine Le Pen in the first round of the 2012 presidential election), coming top in five of the seven interregional constituencies in metropolitan France and a very close second to the UMP in a sixth (the West). The FN achieved first place in no fewer than 16 of metropolitan France's 22 regions, including parts of the country where it had previously made little impression, such as the West and South west. The main locus of resistance to the nationwide wave of FN support was Paris, where the party came fifth with a less than $10 \%$ vote share. Nonetheless, in the greater Paris constituency of Ile-de-France (which included the capital) the FN still managed to come second (17.31\% of vote share) behind the UMP (21.72\%) thanks to its success in some of the towns and suburbs surrounding Paris. The national result gave the FN 24 seats in the European parliament, compared with a mere three in 2009. The success of the FN in the European election meant that under Marine Le Pen's leadership the party had consistently improved on its vote share when compared to the previous equivalent contest under her father's leadership (presidential, parliamentary, municipal and European).

For the UMP the result was a clear failure. The party went from 29 seats in 2009 to 20 in 2014. Copé's leadership, which had apparently been strengthened by the municipal election victory, was immediately called into question. With the party mired in financial scandals concerning false accounting of the 2012 campaign expenses of Sarkozy and alleged inflated payments to a communication company (Bygmalion) with which Copé had close links, his position quickly came under attack from other leading party figures. Copé announced a couple of days after the European election that he was resigning from the post of president of the party.

For the Socialist party the European election result was yet another disaster. While the party lost only one seat (down from 14 in 2009), in terms of vote share this was the worst result ever by the Socialist party in a European election. Moreover, the failure of 
the Socialists was not compensated by gains by other forces of the left. The EELV lost eight seats (down from 14 in 2009).

\section{Evaluation}

The FN had a few spectacular and highly mediatised successes in the municipal election and came out as the leading party in the European contest. The latter result allowed the party to assert that it was now the 'first party in France' - a contested claim that is unlikely to survive the more difficult terrain of the presidential and parliamentary elections in 2017. Yet the picture of relative FN electoral success is not simply reducible to first versus second order electoral contests, with the hypothesis that the party performs better as a repository of protest votes in the latter. Rather, the party tends to score more highly in those elections where local implantation is a less significant factor, such as the highly personalised presidential contest. In contrast, because of poor grassroots organisation in many parts of France the FN tends to do less well in those elections where local or constituency organisation is an important element, for example the municipal and parliamentary contests. In addition, it is clear that there is a growing positive (and not simply protest) vote for the FN.

The aim of Marine Le Pen is to be present in the second round of the presidential contest in 2017. The FN has achieved this feat only once in the history of the Fifth Republic, when Jean-Marie Le Pen narrowly came ahead of the Socialist party candidate, Lionel Jospin, in the 2002 contest, only to be trounced in the second round run-off against the incumbent, Jacques Chirac. With the mid-term unpopularity of the Socialists and the chaotic situation of the UMP, it is by no means beyond the bounds of possibility that Marine Le Pen could reach the second round in 2017 and, if she does so, improve on the $17.79 \%$ vote share of her father in the corresponding round in 2002.

Marine Le Pen has other political objectives. She would like to take advantage of the problems in the UMP to transform the FN into the principal party of the French right. Her detoxification strategy will help in this respect. Blaming globalisation and the European Union for many of France's current socio-economic ills, while at the same time being critical of the alleged 'Islamisation' of France, represents an attractive electoral message for many of 
the excluded, marginalised, bewildered and fearful in French society. At the same time, with electoral success come potential problems, such as having to deliver on promises to voters in those towns run by FN councils.

There is also the difficulty of having to put forward a raft of coherent policies outside of the traditional areas of FN strength, such as immigration, crime and national identity. The more the party seeks to present itself as a 'normal' political party, the more its policies, notably on the economy and on the single European currency, will be subject to closer media and political scrutiny. Marine Le Pen has shown herself to be much less self-assured and persuasive on economic issues in her media interviews. In addition, the FN as yet has made little inroads in terms of electoral representation across the institutions of the Fifth Republic: 'among the roughly half a million French elected representatives the FN has only two MPs, 111 regional councillors, 2 departmental councillors, some 1,600 municipal councillors, no Senator' (Mayer 2014).

The 2014 mid-term elections were a mixed bag for the UMP, which did well in the municipal but badly in the European contest. Since these two sets of elections the party has been thrown into turmoil. The UMP in general and Sarkozy in particular have been at the centre of a raft of scandal allegations since the 2012 elections, with Sarkozy being taken into custody in July 2014 on the grounds that he had tried to abuse his presidential position to exert influence on the judiciary. The party is beset with problems: it is financially in poor condition; party members have been disaffected by the leadership problems and the constant negative media coverage of financial impropriety at the top; the UMP has been unable to carve out a distinctively clear line from the economic policies followed by Hollande; and, provisionally at least, it seems at a loss as to how to deal with the competition from the extreme right, especially as many UMP voters now regard the FN as a natural ally.

In terms of the early jockeying of possible UMP candidates for the 2017 presidential elections, Copé is already out of the race, while Sarkozy is fighting hard to stay in it. There are two other main runners: Fillon and Alain Juppé, who was prime minister during the early part of Chirac's first presidential term and has acquired an 'elder statesman' image in recent years, in part because of his long and widely admired tenure as Mayor of Bordeaux. Both Fillon and Juppé have considerable party political and ministerial experience, they have both 
occupied the office of the premiership, both have been critical of a rightist UMP political line and both are strongly, not to say vehemently, opposed to a new Sarkozy presidential candidacy. Yet Sarkozy's popularity with UMP members and supporters has so far not been irreparably damaged by the torrent of scandal allegations against him and he would relish the chance of a rematch against Hollande. Judicial investigation may well be the best chance for Sarkozy's opponents within the UMP to prevent him from standing as the party's candidate for the third successive time in a presidential election.

Of the three main parties the biggest loser of the 2014 elections was clearly the Socialists. While it is not wholly unexpected for a governing party to be punished by voters in mid-term elections, the scale of the electoral disaffection in both contests was impressive. These were not just defeats for the party, abandoned by many of its core voters, but a humiliating rebuff for the president and his government. By far the more important of the two defeats was the municipal election. The hugely important sub-national stratum of councillors and mayors that Hollande had helped to build up during his period as first secretary of the party (1997-2008) was destroyed in many parts of France, the victories in Paris and Lyons notwithstanding.

President Hollande responded immediately after the debacle of the municipal election. His relaunch initiative consisted of four elements: a change of prime minister, a government reshuffle, a revamped advisory team at the Elysée and a new first secretary for the Socialist party. Of these the appointment of a new prime minister was the most noteworthy. Lacking in charisma in his media appearances, prime minister Jean-Marc Ayrault had never fully succeeded in imposing his authority on government ministers or the parliamentary party. In the light of the severity of the municipal election defeat Ayrault's two strong points - his loyalty to Hollande and managerial competence - proved to be insufficient political assets. The day after the second round he was summarily dismissed and replaced by the minister of the Interior, Manuel Valls. In ideological terms Valls was regarded as being on the right of the Socialist party. He had the reputation for being good at public communication and was popular with public opinion, notably for his strong stance on law and order and his support for the pre-eminence of secular Republican values in dealing with the problems associated with France's multi-ethnic society. 
The appointment of Valls as prime minister indicated no major ideological or policy shift on the part of the president: Hollande had already moved from the social democratic promises of his 2012 campaign to a more 'social liberal' emphasis on the importance of making France more competitive. In December 2013 he had announced a supply-side 'responsibility pact' between business, trade unions and the state in an attempt to encourage business investment and so reduce unemployment. The Ayrault government had also pledged to cut public expenditure by $€ 50$ billion over three years. This two-pronged attempt to improve French economic performance and so reduce unemployment was taken on by Valls, with some minor tweaking to assuage those on the left of the party who regarded the policy as a betrayal of socialist values.

Will the relaunch initiative work as a platform for a Hollande re-election in 2017? Can Hollande successfully restore his battered presidential image? This will in large part depend on an improvement in France's economic performance, over which Hollande and his government have little control. They are dependent on a significant upturn in growth, of which as yet there are no strong signs, and on the willingness of French companies to take on more workers, which is unlikely unless there is an increase in consumer demand. France's regulated labour market helps to protect workers in times of downturn, but also means that firms and businesses can be slower than many EU competitors in responding to new opportunities if and when they arise. In the eyes of business critics longstanding structural problems in the French labour market have as yet not been satisfactorily tackled by Hollande.

In political terms Hollande looks safe for the immediate future. The institutional framework of the Fifth Republic makes it well nigh impossible to get rid of a sitting president. He is still likely to be the Socialist candidate in 2017, if he wishes to run for a second term. His main rival within the Socialist ranks is his new prime minister, who unsurprisingly has dismissed any speculation that he might run against Hollande in a Socialist primary, and who in any case will be implicated in any record of governmental failure over the coming months. As prime minister it will be more difficult for Valls to pursue the 'inside but outside' strategy followed by Sarkozy in his challenge to Chirac during the latter's second presidential term, whereby Sarkozy managed to fight a campaign in the 2007 presidential election as if he had not been a long-standing 
member of the government (Kuhn 2007). In short, Hollande's unpopularity with Socialist party members and core electorate is not sufficient to undermine a second presidential candidacy unless another credible Socialist candidate can be persuaded to stand against the incumbent. This is not an impossible scenario, but it is an unlikely one.

Hollande emerged from the 2014 mid-term elections seriously weakened, but not fatally wounded. An unanticipated bonus for him was the internal strife that crippled the capacity of the UMP to present itself as a credible alternative. Rarely in the history of the Fifth Republic have the two mainstream forces of left and right simultaneously seemed so bereft in terms of leadership, strategy, credibility and voter confidence. Such a situation is manna for Marine Le Pen and the FN. She will not win the 2017 presidential election; but the ideas of her party may well set the tone for the campaign.

Table 1: Hollande's popularity: May 2012-April 2014

\section{Total des personnes satisfaites de François Hollande}

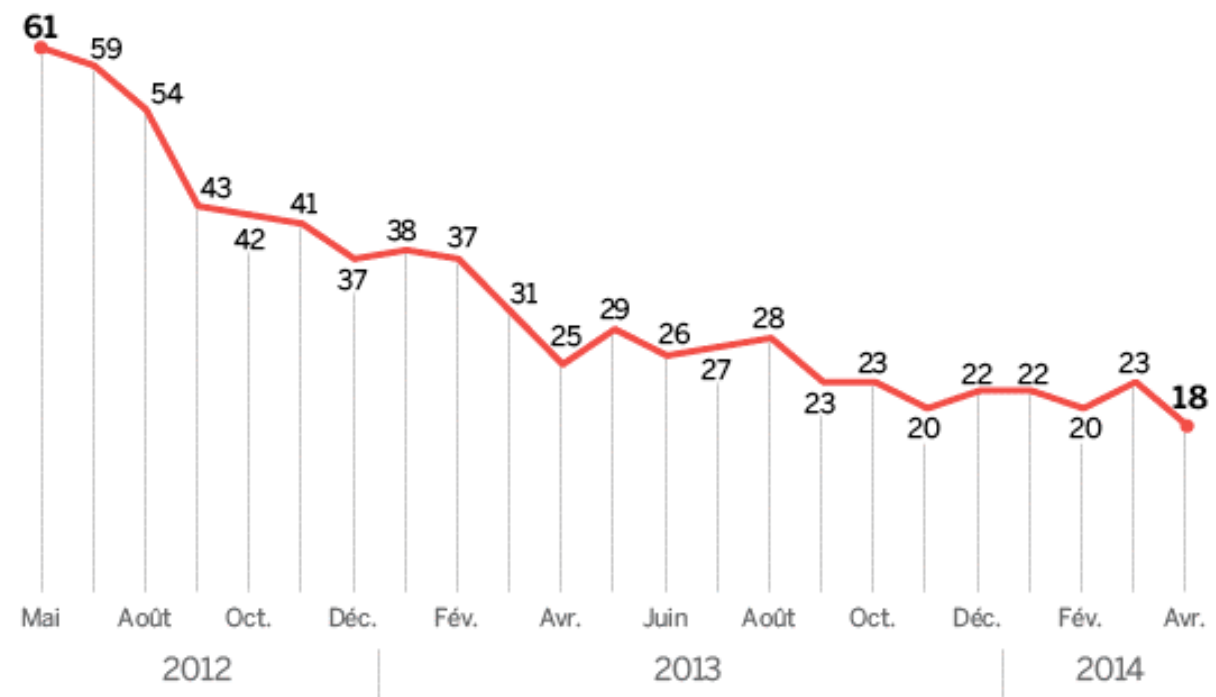

Source : Enquête réalisée par téléphone sur un échantillon de 1800 personnes, représentatif de la population française âgée de 18 ans et plus. (D) LeMonde.fr/lesdecodeurs

Source: IFOP poll, Le Monde, 7 May 2014.

\section{REFERENCES}

BARJON, CAROLE and BRUNO JEUDY. 2013. Le coup monté. Paris: Plon. 
BRIGAUDEAU, ANNE. 2014. Comment Hénin-Beaumont, fief du PS, est tombé dans l'escarcelle du FN.

http://blog.francetvinfo.fr/livres-actualite/2014/03/23/comment-heninbeaumont-fief-du-ps-est-devenu-le-laboratoire-du-front-national.html (accessed 4 July 2014).

CHAFFANJON, CHARLOTTE. 2013. Jérôme Cahuzac, les yeux dans les yeux. Paris: Plon.

GUÉNOLÉ, THOMAS. 2013. Nicolas Sarkozy, chronique d'un retour impossible?. Paris: First Document.

HAEGEL, FLORENCE. 2012. Les droites en fusion: Transformations de l'UMP. Paris: Les Presses de Sciences Po.

IGOUNET, VALÉRIE. 2014. Le Front National. Paris: Seuil.

KUHN, RAYMOND. 2007. The French presidential and parliamentary elections, 2007. Representation 43(4): 323-36.

KUHN, RAYMOND. 2013. The French presidential and parliamentary elections, 2012. Representation 49(1): 97-114.

MAYER, NONNA. 2014. 'The Front National: How far from the Elysée?' Policy Network Observatory. http://www.policynetwork.net/pno_detail.aspx?ID=4661\&title=The-Front-National-How-farfrom-the-Elysée (accessed 25 July 2014)

MINISTRY OF THE INTERIOR. 2014a. http://www.interieur.gouv.fr/Elections/Lesresultats/Municipales/elecresult_MN2014/(path)/MN2014/FE.html (accessed 8 July 2014).

MINISTRY OF THE INTERIOR. 2014b. http://www.interieur.gouv.fr/Elections/Actualites-des-elections/Dossierelections-municipales-2014/Annexe-15-Statistiques-concernant-les-femmeselues (accessed 21 July 2014).

MINISTRY OF THE INTERIOR. 2014c. http://www.interieur.gouv.fr/Elections/Lesresultats/Europeennes/elecresult_ER2014/(path)/ER2014/FE.html (accessed 8 July 2014).

PAILLÉ, DOMINIQUE. 2013. Sarkozy, Retour perdant. Paris: 1'Archipel. 
PERRINEAU, PASCAL. 2014. La France au Front. Paris: Fayard.

SABÉRAN, HAYDÉE. 2014. Bienvenue à Hénin-Beaumont. Paris: La

Découverte.

SHIELDS, JAMES. 2013. Marine Le Pen and the 'New' FN: A Change of Style or of Substance?. Parliamentary Affairs 66(1): 179-96.

VAUDANO, MAXIME. 2014. Municipales : pourquoi la parité a échoué. http://abonnes.lemonde.fr/les-decodeurs/article/2014/04/03/municipalespourquoi-la-parite-aechoue_4394919_4355770.html?xtmc=parrite_municipales_2014\&xtcr=5 (accessed 21 July 2014).

Raymond Kuhn is Professor of Politics at Queen Mary University of London. He has published widely on French politics and political communication.

E-mail: r.kuhn@qmul.ac.uk 